\title{
CZYM JEST KULTUROLOGIA?
}

\section{EDWARD KASPERSKI}

Wydział Polonistyki Uniwersytetu Warszawskiego;

Faculty of Polish Studies at the University of Warsaw (Poland)

e.kasperski@uw.edu.pl

\section{Kontekst, przedmiot i wlaściwości kulturologii}

Kulturologia zajmuje się badaniem kultury z myślą o objęciu całości, poznaniu jej złożoności i zachodzących w niej procesów oraz wskazaniu właściwości, stanowiących o jej hipotetycznej jedności oraz o względnej różnicy w stosunku do innych dziedzin bytu ${ }^{1}$. Trudnością w rozwiązywaniu tego zadania jest jednakże to, iż - dosłownie rzecz biorąc - owa „całość” kultury wykazuje naturę prowizoryczną, nietrwałą, ruchomą, wielokształtną oraz nieprzerwanie zmienia swoją zawartość i granice. Jej zasoby obejmują bowiem tak różnorodne klasy artefaktów - niesprowadzalne, zdawałoby się, w żaden sposób do wspólnego mianownika - jak: narzędzia, utensylia,

${ }^{1}$ Geneza terminu 'kulturologia' jest sama w sobie złożona. Za jego wynalazcę uznaje się niemieckiego uczonego Wilhelma Friedricha Ostwalda, chemika i filozofa, laureata nagrody Nobla w dziedzinie chemii, autora pracy Energetische Grundlagen der Kulturwissenschaft (1909), który po raz pierwszy użył go w odniesieniu do kultury w 1913 roku. Rozgłos i szerokie znaczenie nadał jednakże terminowi amerykański antropolog i teoretyk kultury, Leslie A. White (1900-1975). Zob. Robert L. Carneiro, Leslie A. White, [w:] Totems and Teachers: Key Figures in the History of Anthropology, red. S. Silverman, Walnut Creek 2004, s. 165-165. Cyt. wg https://www.google.pl/search?tbm=bks\&hl=pl\&q=Totems+and+Teachers\%3A+Key+Figures + in +the+History+of + Anthropology [data dostępu: 10.10.15]. Termin kultura omawia Claus-Michael Ort, Kulturbegriffe und Kulturtheorie, [w:] Konzepte der Kulturwissenschaften. Theoretische Grundlagen - Ansätze Perspektiven, red. Ansgar Nünning, Vera Nünning, Stuttgart 2003, s. 19-20. 
maszyny, środki transportu, architekturę, odkrycia nauki, dzieła plastyki, muzykę, teksty językowe, obyczaje, instytucje, rytuały świeckie i religijne itd. Wszystkie one ponadto ewoluują w czasie i różnią się zależnie od typu społeczeństwa i jego usytuowania w przestrzeni. Powoduje to, że łatwiej wyróżniać oraz identyfikować kultury tworzone i praktykowane przez te czy inne społeczności, usytuowane w konkretnym czasie i określonej przestrzeni, niż charakteryzować „kulturę globalną” lub „kulturę w ogóle”.

To samo stosuje się zresztą do odrębnych działów kultury (obyczaje, różne sztuki, technika, konsumpcja itd.), które w odróżnieniu od skrajnie heterogenicznej i wewnętrznie zróżnicowanej całości kultury charakteryzują się względną jednorodnością, trwaniem w czasie i potencjałem dyfuzji. Inną cechą kultury - również przeszkodą w jej zdefiniowaniu - jest to, iż bywa ona w zmiennych, dynamicznych relacjach do tego, co uznaje się za obszary pozakulturowe (bywają nimi na przykład przyroda, religia lub nauka) ${ }^{2}$. Osobne trudności sprawia ponadto sam sposób ustalania oraz konceptualizacja wspomnianej całości. Konkurują ze sobą w tej dziedzinie rozmaite ujęcia aprioryczne, empiryczne procedury opisowo-indukcyjne i badania porównawcze ${ }^{3}$.

Wszystkie te niedogodności wskazują zatem, że ogólne charakterystyki kultury wymykają się definicyjnemu unieruchomieniu i wyczerpaniu i że one same, podobnie jak ich przedmiot - kultura - podlegają kulturowym

${ }^{2}$ Prawdą jest jednakże to, że obszary pozakulturowe wywierają określony wpływ na kulturę i znajdują w niej swój symboliczny, tekstowy i dialogowy wyraz (na przykład klimat, który motywuje niezliczone potoczne, medialne, artystyczne i naukowe dyskursy o pogodzie), podobnie zresztą jak kultura oddziałuje z kolei wszechstronnie na kształt przyrody za pośrednictwem udomowienia zwierząt, rolnictwo, ogrodnictwo, parki, eksploatację zasobów naturalnych czy ekologię.

3 Przykładem tych ostatnich bywają tak zwane cross-cultural studies. Zob. Michael Minkov with contribution by Geert Hofstede, Cross-Cultural Analysis. The Science and Art of Comparing the World's Modern Societies and Their Cultures, Sage 2013. 
relatywizacjom. Próby wykrycia i rekonstrukcji jednolitego, trwałego symbolicznego i/lub systemowego porządku kultury, ongiś tak chętnie podejmowane przez strukturalistów, napotykają więc przeszkody, zdawałoby się, nie do pokonania. Trafnie charakteryzował je w kategoriach „kolizji systemów kulturowych” estońsko-rosyjski kulturolog i literaturoznawca Jurij Lotman:

Historię kultury dowolnego narodu można rozważać z dwóch punktów widzenia: po pierwsze, jako rozwój immanentny, po drugie, jako rezultat różnorodnych wpływów zewnętrznych. Oba te procesy wzajemnie splatają się ze sobą, ich rozdział jest możliwy jedynie za pośrednictwem i w toku abstrakcji badawczej. Toteż dowolne rozpatrywanie w izolacji zarówno ruchu immanentnego, jak i wpływów prowadzi nieuniknienie do zniekształcenia obrazu. Złożoność zjawiska zawiera się jednakże wcale nie w tym, lecz w tym, że każdy kolizyjny styk różnych systemów zwiększa nieprzewidywalność dalszego ruchu. Przypadek, kiedy zewnętrzne wtargnięcie powoduje zwycięstwo jednego ze zderzających się systemów i porażkę drugiego, nie obejmuje bynajmniej wszystkich tego rodzaju sytuacji. Bardzo często kolizja rodzi bowiem coś trzeciego, istotnie nowego, co wcale nie okazuje się oczywistym, logicznie przewidywalnym następstwem któregokolwiek z systemów uczestniczących w danej kolizji. Rzecz komplikuje się także z tego względu, iż powstające nowe zjawisko bardzo często przybiera nazwę wywodzącą się z jednego spośród kolidujących ze sobą systemów, kryjąc w ten sposób za starą fasadą coś zasadniczo nowego ${ }^{4}$.

W określeniu trwałego porządku kultury tworzy zatem owe przeszkody w pierwszym rzędzie jej dynamiczna produktywność: pojawianie się nowych zjawisk, form i tworów w różnych dziedzinach oraz wypadanie $\mathrm{z}$ obiegu istniejących lub oswojonych. Innym czynnikiem zakłóceń bywa z kolei nakładanie się na siebie, mieszanie ze sobą oraz przemieszczanie się rozmaitych wzorów, zachowań i artefaktów. Siłą sprawczą bywają tu globalne

${ }^{4}$ Jurij Lotman, Культура и взрыьв, [w:] tegoż, Семиосфера, С.-Петербург 2000, http://yanko.lib.ru/books/cultur/lotman_semiosphera.htm [data dostępu: 11.10.15], s. 63. Wszystkie tłumaczenia, o ile nie podaje się nazwiska tłumacza - E.K. 
i regionalne procesy transkulturowe. W przeszłości inicjowała je na przykład chrystianizacja Europy i Ameryki, islamizacja znacznych połaci Afryki i Azji czy afrykanizacja kontynentu amerykańskiego za sprawą importu niewolników. Nie ustały one zresztą i współcześnie, pobudzane przez globalizację rynku, Internet albo chociażby amerykanizację. Z kolei powszechne oddziaływanie na siebie oraz wzajemne przenikanie się rozmaitych kultur i cywilizacji - ongiś dla siebie nieczytelnych, obcych lub nieprzystępnych - sprzyja powstawaniu nowych, hybrydycznych formacji kulturowych oraz wyłanianiu się ognisk interkultury ${ }^{5}$, która stanowi alternatywę zarówno dla praktyk kulturowego etnocentryzmu i segregacji (na przykład w stosunku do Aborygenów lub egzotycznych imigrantów), jak i dla zjawisk akulturacji i asymilacji przez dominującą kulturę.

Wspomniane przemiany nie przebiegają jednakże bez zgrzytów i konfliktów. Idylliczne obrazy bezkolizyjnej wymiany lub harmonijnego kulturowego ładu zakłócane są przez praktyki narzucania hegemonii, niwelowania odrębności właściwych mniejszościom etnicznym, językowym czy religijnym, podległym i zależnym militarnie, w sferze władzy politycznej lub ekonomii. Wyrazem takiej postawy stały się praktyki tzw. etnocydu (ang. cultural genocide), stosowane dziś w niektórych regionach Europy, Bliskiego Wschodu, Azji czy Afryki, wynikające z przekonania, iż należy wymazać ślady odrębnej tożsamości i kultury u mniejszości i upodobnić ją do hegemona.

Wymienione okoliczności i procesy powodują, że liczne próby określenia „istoty kultury” - jednym z wzorców może być tytuł dawnej książki Alfreda Kroebera The Nature of Culture (Chicago 1952) - kończą się często zawo$\mathrm{dem}^{6}$. Wywołują one bowiem zarzuty o normatywizm i esencjalizm, gdyż

${ }^{5}$ Pojęcie to wprowadził i spopularyzował Mark Terkessidis, Interkultur, Berlin 2010.

${ }^{6}$ Szerokie spectrum definicji kultury dokonywanych $\mathrm{z}$ różnych pozycji teoretycznych zestawiała ongiś rozprawa: Alfred L. Kroeber, Clyde Kluckhohn, Culture. A Critical Review of Concepts and Definitions, Cambridge 1952. Z kolei 
utrwalają w owej ,istocie” preferowany typ kultury kosztem ograniczenia pluralizmu, różnorodności i zmienności poszczególnych kręgów (,podsystemów”) kulturowych. Podobnych pułapek, które musi obejść kulturologia, jest więcej. Nie uzasadnia to jednak, jak wolno sądzić, ani rezygnacji z poszukiwania tego, co stanowi o kulturze w odróżnieniu od nie-kultury, ani też tego, co wspólne w pstrokatej, zdawałoby się, wielości, różnorodności i zmienności kultur. Nie wydaje się, by negowanie idei - choćby tylko hipotetycznej - jedności i wspólnoty kultur było tu na miejscu, zwłaszcza w sytuacji, gdy przyjmuje się założenie, iż podobne badanie nie powinno zacierać różnic i odrębności. Skoro jednak wiedzy o kulturze nie sposób wyczerpać indukcyjnie, zamknąć w jednolitym systemie lub ustalić drogą aprioryczną, pozostaje metoda przybliżeń, która wprawdzie nie aspiruje do rangi wiedzy niepodważalnej, ale kreśli pewien „możliwy” obraz kultury, podległy korektom i falsyfikacji. I taką drogą postępuje (czy też powinna postępować) kulturologia.

Nie wyrzeka się ona zatem racjonalnych procedur badawczych, potępianych niekiedy za logocentryzm przez naśladowców Jacques’a Derridy. Nie daje się również sprowadzić do szczegółowych badań empirycznych i tych, które koncentrują się na konkretnych zjawiskach, jak dajmy na to, teatr Kantora, powieści Elfriede Jelinek lub graffiti na murach miejskich w Warszawie. Wykracza poza badanie samodzielnych działów kultury, jak obyczaje, teatr, muzyka, malarstwo, literatura, polityka czy media ${ }^{7}$. Nie

krytyczny, wnikliwy przegląd prozycji definicyjnych z punktu widzenia kulturologii prezentował artykuł Lesliego L. White'a, The Concept of Culture, „American Anthropologist", New Series, Vol. 61, No. 2 (Apr., 1959), s. 227-251.

${ }^{7} \mathrm{Nie}$ znaczy to, że kulturologia ignoruje tego typu badania. Respektuje ona w tym względzie zasadę dekonstrukcji całości jako chwyt metodyczny, zob. Adam Kuper: ,to understand culture, we must first deconstruct it. Religious beliefs, rituals, knowledge, moral values, the arts, rhetorical genres, and so on should be separated out from each other rather than bound together into a single bundle labeled culture [...]",[,,aby zrozumieć kulturę, musimy ją najpierw zdekonstruować. Przekonania 
zamyka kultury w enklawach etnicznych, by wspomnieć opisywane przez Claude'a Lévi-Straussa artefakty i zwyczaje ludów Guaycuru i Bororo w Ameryce Południowej oraz inne, niezliczone studia etnografów, etnologów czy antropologów. Nie zawęża jej do kryteriów społecznych, by wymienić z kolei tytułem przykładu badania nad obyczajowością mieszczańską lub socjologiczne studia na temat więzi sąsiedzkich na wsi. Nie sposób też utożsamić kulturologii z historią kultury, mimo podejmowanych w ostatnich dekadach starań Stephena Greenblatta, nowego historyzmu i poetyki kultury, a także licznych opisów i prób wyodrębnienia kultury antyku, średniowiecza, renesansu, baroku czy oświecenia. Nie zlewa się kulturologia także z takimi naukami humanistycznymi, jak psychologia, socjologia, semiotyka czy antropologia. Nauki te wprawdzie interesują się zjawiskami kulturowymi, lecz czynią to w zasadzie pochodnie, ogniskując własne zainteresowania na psychice, zachowaniach zbiorowych, relacjach międzyludzkich, społeczeństwie, typach znaków i systemach znakowych lub gatunkowych właściwościach i wyróżnikach człowieka (homo sapiens). Nie ma też kulturologia, rzecz jasna, bezpośrednio do czynienia z naukami przyrodniczymi i ścisłymi, które kierują uwagę na zjawiska ex definitione inne niż kulturowe.

Konkluzja płynąca z tych wyliczeń jest taka, że kulturologia nie zajmuje się ani wydzieloną częścią kultury, ani jej wyróżnionym działem, ani tym czy innym aspektem lub funkcją, lecz całością. Powyższe uwagi nie prowadzą jednakże do wniosku, że kultura jako taka powstaje i funkcjonuje poza obrębem ludzkiej psychiki i działalności, zadzierzganych więzi i interakcji międzyludzkich, społeczeństwa, instytucji, publicznego i prywatnego

religijne, rytuały, wiedza, wartości moralne, sztuki, gatunki retoryczne, itd. powinny być od siebie oddzielone, a nie połączone w jeden pakiet zwany kulturą" - tłum. M.C.] Culture. The Anthropogist's Account, Cambridge 1999, s. 245. Warto zauważyć, że istnienie względnie odrębnych segmentów kultury nie anuluje jednakże pytania ani o ich wzajemne oddziaływanie na siebie i przenikanie się, ani też o aktualne miejsce w dynamicznej, stale zmieniającej się całości kulturowej. 
komunikowania się, cyrkulacji znaków, języków, tekstów i dyskursów. Nie zakładają także, iż pozostaje ona obojętna na bodźce biologiczne i ekologiczne, podtrzymujące i kształtujące życie ludzkie. Nie sugerują, rzecz jasna, że jej formy nie zmieniają się w czasie i przestrzeni oraz pozostają zawsze i wszędzie te same i takie same (,równe sobie”), niezależnie od epoki, grupy etnicznej lub klasy społecznej czy okoliczności. Kulturologia akceptuje zatem pogląd, iż formy, wydarzenia i zjawiska kulturowe wpisują się w życie, działalność i właściwości człowieka, społeczeństwa, cywilizacji i historii, słowem, wchodzą w rozliczne związki ze zjawiskami innymi niż sama kultura.

Swoistość kulturologii tkwi jednakże w czymś innym. Otóż nauki, jak antropologia, socjologia, psychologia, ksenologia czy historia kultury włączają tę ostatnią w struktury wobec niej bytowo i jakościowo innorodne. Podporządkowują ją im i nierzadko w nich rozpuszczają. Tak właśnie funkcjonują antropologia kultury, socjologia kultury czy też semiotyka kultury. Utożsamiają one czynniki kulturowe odpowiednio z antropologicznymi, socjologicznymi, psychologicznymi, semiotycznymi itd. Nie sposób wówczas precyzyjnie ustalić, co jest „kulturowego” w antropologii, socjologii czy semiotyce kultury oraz na ile pierwiastki te mają charakter samodzielny lub stanowiący, a na ile zaś tylko zależny i podporządkowany

Refleksja kulturologiczna próbuje zmierzyć się z tą sytuacją. Przyjmuje ona, że zjawiska kulturowe należą z samej swej istoty bytowej do pojemnej, wewnętrznie zróżnicowanej kategorii artefaktów, a nie zaś do przyrody organicznej czy nieorganicznej. Nie wyczerpują ich właściwości i funkcji

\footnotetext{
${ }^{8}$ Rozgraniczenie takie jest o tyle trudne, o ile o kulturze stanowią nie tylko przypisane artefaktom znaczenia, lecz także pierwiastki materialne: na przykład kamień, metal czy drewno w rzeźbie, farby w malarstwie, tekstylia, skóry, szkło, plastyk w kolażach, kostiumy i rekwizyty w teatrze itp. W sztuce nowoczesnej odgrywają one zwykle pierwszoplanową rolę, zarówno konstrukcyjną, jak i znaczeniową (,duchową").
} 
prawa biologii lub fizyki. Tymczasem z przyrodą liczą się na przykład w tym czy innym stopniu antropologia, analizująca stosunki pokrewieństwa, psychologia, która bada cechy wrodzone i odruchy bezwarunkowe, oraz nauki o społeczeństwie, uwzględniające nie tylko organizację i ustrój społeczeństwa, lecz także wpływ zastanych warunków naturalnych (położenia geograficznego, klimatu, zasobów naturalnych) na sposób życia zbiorowości.

Tymczasem zjawiska kulturowe osadzają się w pierwszym rzędzie w ludzkich właściwościach, zachowaniach i działaniach sprawczych: w intelekcie, nabytych kwalifikacjach, stosowanych technikach, wiedzy, istniejących wzorach, kunszcie wykonania, obyczajach i zwyczajach, emocjach, wyobraźni, wrażliwości. Stanowią summa summarum ich pochodne. Podlegają zarazem społecznej cyrkulacji, odrywają się od swoich wytwórców, użytkowników i konsumentów, usamodzielniają się w tym czy innym stopniu, zwrotnie oddziałują na swoich twórców i odbiorców. Cyrkulacja tego rodzaju nierzadko zmienia, modyfikuje lub aktualizuje ich pierwotne właściwości i przeznaczenie. Wespół z materialnymi nośnikami i znaczeniami współkonstytuuje ona rzeczywistość kultury.

Inaczej niż przyczynowo zdeterminowana przyroda, pozostaje ona w określonych granicach arbitralna (dowolna), umowna i „plastyczna”. Jej twory podlegają reprodukcji oraz bywają przenośne, „wędrowne”, wymienne i zastępowalne ${ }^{9}$. O ich losach w znacznym stopniu - nie w każdej jednakże sytuacji - rozstrzygają wybory, decyzje, działania i reakcje podmiotów kultury. Formują one intersubiektywne i transkulturowe konwencje, wzorce gatunkowe oraz kształtują osadzone w danym środowisku tradycje,

\footnotetext{
${ }^{9}$ Pogląd o zmienności, zastępowalności czy wymienności elementów kulturowych pozostaje często w sprzeczności z etnocentryczną wizją kultury, która akcentuje jej ludowe korzenie, organiczny charakter, trwanie, swoistość, niewymienność i niezastępowalność. Zob. Wolfgang Kaschuba, Anmerkungen zum Gesellschaftsvergleich aus ethnologischer Perspektive, http://edoc.hu-berlin.de/oa/bookchapters/resf43HGISZo/PDF/23uDV5SvKdUoc.pdf [data dostępu: 13.10.15], s. 3.
} 
podobnie zresztą jak wypadają z obiegu i nikną. Angażują realnie działające siły kulturotwórcze: istniejący indywidualny, społeczny i rzeczowy potencjał (,,kapitał”) kulturowy, w tym symboliczny. Decydują zarówno o tworzeniu, reprodukcji i podtrzymywaniu określonych systemów, form i wartości kulturowych, jak też o ich modyfikacji, zmianie, rozszerzeniu, redukcji czy uchyleniu. Wpływają więc na wspomniany uprzednio nieprzerwany obieg dzieł, form i wartości zarówno w danym kręgu kulturowym, jak i pomiędzy takimi kręgami oraz w skali uniwersalnej ${ }^{10}$.

Właściwości te rozstrzygają zatem o bytowej, jakościowej i funkcjonalnej specyfice zjawisk kulturowych. Powodują, iż można i należy je rozważać nie tylko w kontekście oraz w relacji do jakościowo innych zjawisk bytowych - do ludzkiej psychiki, stosunków lub zachowań międzyosobniczych, społeczeństwa, historii, przyrody - lecz także, by wyrazić to w języku filozofii, „w sobie i dla siebie”, w szczególności ze względu na właściwą im zdolność symbolizowania, archiwizowania i przekazywania znaczeń oraz ekspresywnego (w tym estetycznego) oddziaływania. Ujęcie takie, warto podkreślić, warunkuje pod względem epistemologicznym i metodologicznym samą możliwość uprawiania kulturologii - inaczej zatraciłaby ona przedmiotową i teoretyczną odrębność i upodobniłaby się do szczegółowych nauk o kulturze.

Należy rozróżnić tu z jednej strony lingwistyczne systemy językowe (np. mowa) i semiotyczne systemy znakowe (np. morski kod sygnalizacyjny) wyspecjalizowane w przekazywaniu znaczeń i formułowaniu komunikatów oraz, z drugiej strony, wszelkie inne obiekty służące prymarnie odmiennym celom - na przykład produkcji, konsumpcji lub działaniom militarnym - które mogą również pełnić w określonych sytuacjach funkcje znakowe (symboliczne), komunikować określone znaczenia i oddziaływać

${ }^{10}$ Przykładem może być ekspansja literatury i istnienie zauważonej przez Johanna Wolfganga Goethego ponadnarodowej literatury światowej (Weltliteratur). 
ekspresywnie. Takie funkcje pełnią w różnych kulturach np. chleb, sierp czy miecz ${ }^{11}$. Zdaniem L.A. White'a zdolność pełnienia przez dany obiekt funkcji symbolicznej (językowej, znakowej, komunikacyjnej) rozstrzyga o jego przynależności do kultury, aczkolwiek nie wyklucza innych zastosowań, dajmy na to, w charakterze narzędzia pracy (sierp, młot, motyka, siewnik, waga, cyrkiel, kielnia itd.), przedmiotu konsumpcji (chleb, zboże, winogrona, ryby, kukurydza, jabłka itd.) czy uzbrojenia (miecz, łuk, włócznia, karabin, armata itd. ${ }^{12}$. Nie eliminuje też możliwego oddziaływania ekspresywnego (estetycznego). Taka wieloaspektowość i wielofunkcyjność artefaktów należących do kultury życia codziennego różni je od tych, które, jak język artykułowany, specjalizują się w określaniu i przekazywaniu znaczeń.

Otóż kulturologia zajmuje się tymi zjawiskami, które - niezależnie od innych, praktycznych zastosowań (narzędzi, pożywienia, odzieży, ozdób itd.) - pełnią lub są w stanie pełnić, po pierwsze, funkcje symboliczne, a więc przekazywać znaczenia i komunikaty, po drugie, tworzą w tym względzie osobną klasę wewnętrznie powiązanych artefaktów, czyli kulturę w węższym tego słowa znaczeniu. Zdolność i funkcja wyrażania i przenoszenia

${ }^{11} \mathrm{~W}$ rozdziale Symbol w systemie kultury J. Lotman określa symbol jako „pewną treść, która służy z kolei jako plan wyrażenia dla innej, z reguły kulturowo cenniejszej treści (некоторое содержание, которое, в свою очередь, служит планом выражения для другого, как правило, культурно более ценного, содержания), Культура и взрьгв, [w:] Семиосфера, ор. cit., s. 240. W planie wyrażania i treści symbol uosabia $\mathrm{w}$ powyższym rozumieniu określony tekst zawierający sprecyzowane znaczenia i granice, pozwalające rozpoznać konkretny symbol w danym kontekście znakowym i tekstowym. Znamieniem symboli kulturowych są ponadto: 1) tkwiące w nich pierwiastki archaiczne, toteż ukryta w symbolach pamięć sięga zazwyczaj czasów przedhistorycznych, 2) wewnętrzna pamięć symboli bywa z zasady starsza niż ich współczesne językowe i tekstowe otoczenie (kontekst), 3) symbole z racji swej archaiki i trwałości kształtują ciągłość kultury, 4) ich zestawy określają tożsamość poszczególnych kultur, aczkolwiek 5) te czy inne symbole podlegają również międzykulturowym migracjom i swego rodzaju internacjonalizacji, połączonej nierzadko z modyfikacją znaczenia.

${ }^{12}$ Zob. L.A. White, The Concept of Culture, op. cit., s. 230-233. 
znaczeń oraz uczestniczenia w komunikacji międzyludzkiej odróżnia de facto substancjalnie, pragmatycznie i funkcjonalnie klasę zjawisk kulturowych - wewnętrznie zdywersyfikowanych - od przyrody, produkcji, techniki i konsumpcji. Zasadnicza różnica zawiera się tu w tym, iż znaki i symbole wskazują (znaczą) z samej swej istoty coś innego niż tylko same siebie, podczas gdy twory nieznakowe są w zasadzie równe sobie samym. Uzyskują one ontologiczny status rzeczy (res) oraz podlegają opisowi i użyciu, by tak rzec, w sobie samych.

Wyłania to potrzebę wyodrębnienia także innych cech kultury na tle obiektów pozakulturowych, a także w zestawieniu z nimi, zwłaszcza z tymi, które wprawdzie pełnią funkcje symbolizowania, lecz ich właściwości i funkcje nie sprowadzają się do tworzenia, przekazywania czy archiwizowania znaczeń, gdyż uczestniczą one w takich utylitarnych, towarowych czy administracyjnych sferach ludzkiej działalności, jak produkcja, konsumpcja, dystrybucja, handel, militaria, prawo itd. Nie ulega wątpliwości, że sfery te wyciskają swoje znamię na zjawiskach kulturowych. Wywierają znaczący wpływ na dziedziny, które, jak język artykułowany czy inne umowne systemy znakowe, służą w pierwszym rzędzie wyrażaniu i przekazywaniu znaczeń. Również te dziedziny pograniczne wchodzą w pole widzenia kulturologii - bez nich postrzeganie kultury byłoby wybiórcze, zawężone na przykład do kultury artystycznej, a tym samym ułomne.

Postępowanie wyodrębniające pierwiastki sensu stricto kulturowe nie oznacza zatem, wypada zaznaczyć z naciskiem, uznania ich za izolowane, samoistne i samodzielne, ,działające wyłącznie na własną rękę", nie wchodzące w jakiekolwiek „mezaliansowe” związki i zapośredniczenia z organiczną lub nieorganiczną przyrodą, społecznym otoczeniem lub techniką. Nie oznacza też braku interakcji lub uwarunkowań. Owe związki, zapośredniczenia, interakcje i uwarunkowania stanowią natomiast owocne i prawomocne pole badań takich przywołanych uprzednio nauk, jak historia, socjologia, antropologia, psychologia czy ekologia kultury - o ile, rzecz jasna, badania 
te nie zastępują z kolei pierwiastków kulturowych somatycznymi, psychicznymi, egzystencjalnymi, socjalnymi, politycznymi czy środowiskowymi.

Wspomniana problematyka interesuje także praktykowane zwłaszcza w Niemczech i nachylone ku kulturze Geisteswissenschaften, wydobywające z niej w pierwszym rzędzie czynniki duchowe: moralne, światopoglądowe i mentalne. Na przeciwnym biegunie można natomiast umieścić wywodzące się z Wielkiej Brytanii cultural studies, ukierunkowane na ogół materialistycznie, zainicjowane pracami szkoły z Birmingham (Centre for Contemporary Cultural Studies), inspirowane pracami Stuarta Halla czy Raymonda Williamsa, inicjatora kierunku zwanego kulturowym materializmem, a także wielu badaczy z innych krajów: Niemiec (szkoła frankfurcka), Francji (Louis Althusser), Włoch (Antonio Gramsci), USA (kierunek new historicism). Wyliczenie to nie obejmuje zresztą pełnego zakresu międzynarodowej ekspansji cultural studies ${ }^{13}$.

Ich znaczenie dla kulturologii wyraża się zwłaszcza w tym, iż podejmują one w szczególności aktualne i żywotne - wcześniej nierzadko spychane na margines - zagadnienia z zakresu socjologii kultury, polityki kulturalnej, ideologii, władzy, hegemonii, kolonializmu i postkolonializmu, tożsamości kulturowej, płci, ruchów emancypacyjnych, transgresji. Dotyczą przemian i przesunięć, które zmieniają obraz i mapę ,internacjonalizującej się”, ponowoczesnej kultury współczesnej. Badają sposoby manipulowania kulturą przez ośrodki władzy. Rozszerzając samo pojęcie kultury, omawiany nurt wychodzi poza uprzywilejowane dawnej ramy kultury „wysokiej”,

${ }^{13}$ Zob. Moritz Baßler, New Historicism, Cultural Materialism und Cultural Studies, [w:] Ansgar Nünning, Vera Nünning (red.), Konzepte der Kulturwissenschaften. Theoretische Grundlagen - Ansätze - Perspektiven, Stuttgart 2003, s. 132-155. Kierunki te Baßler traktuje jako całość, dodając do niej: ,analizę dyskursu” Michela Foucaulta, koncepcję „gęstego opisu” (thick description) Clifforda Geertza, Paula de Mana „alegorie czytania” i „poetykę kultury” Stephena Greenblatta, wyłożone przez niego w artykule Towards a Poetics of Culture (,Southern Review”, vol. 20, no.1, Mar 1987, s. 3-15). 
„elitarnej” czy ,awangardowej”. Uwzględnia natomiast w szerokim zakresie kulturę życia codziennego czy też warstw upośledzonych, problematykę przemysłu kulturalnego i wytwarzaną przez niego kulturę masową, kulturę popularną, działalność nowych mediów w tym zakresie (telewizji, Internetu, telefonii komórkowej, wideo, reklamy). Śledzi, innymi słowy, bieżące innowacje technologiczne $\mathrm{i}$ bada ich wpływ na przekazy i transformacje kulturowe. Nie pomija istnienia subkultur młodzieżowych, kulturowego podziemia (undergroundu) czy kontrkultury. Wspomniane badania, z jednej strony, adaptują i modyfikują do własnych zadań pojęcia kulturoznawcze i kulturologiczne, z drugiej zaś - same oddziałują zwrotnie na kulturologię. Ich znamieniem pozostaje jednak to, iż sytuują zjawiska kulturowe zasadniczo w perspektywie współczesnych transformacji cywilizacyjnych i społecznych. Charakteryzuje je nierzadko postawa publicystyczna, demaskatorska i krytyczna.

Wspomniana problematyka związków kultury z szeroko rozumianą „nie-kulturą" nie stanowi natomiast, jak wynika z poprzednich uwag, głównego i bezpośredniego przedmiotu kulturologii, która dąży do wyjawienia i ustalenia przede wszystkim tego, co stanowi o „kulturze w kulturze”. Unika ona $\mathrm{w}$ tym wypadku również podmiany znaczeń kulturowych na problematykę ich materialnych i technologicznych nośników, zgodnie z mylącą tezą McLuhana, iż ,samo medium jest prymarnym przekazem”. Nie oznacza to jednak niezauważania lub niedocenienia przez kulturologię owych technicznych lub elektronicznych nośników, ponieważ znamieniem współczesnej symbolizacji i tekstualizacji kulturowej jest to, iż coraz częściej odwołują się one do tego typu nośników, aczkolwiek nośniki te, pozostawione samym sobie i oderwane od przekazu relewantnych znaczeń, wypadają z kulturowego obiegu i zaludniają domenę (złomowisko?) głuchych i milczących rzeczy „samych w sobie”. 


\section{Delimitacje kultury}

Jednym z zadań kulturologii jest bez wątpienia delimitacja kultury: refleksja o jej zakresie i granicach. Utrwalił się w tej materii pogląd - i nie sposób odmówić mu pewnej racji - iż kultura nie tylko powstaje za sprawą gatunku homo sapiens, lecz także historycznie konstytuuje go i wyraża. Dysponowanie kulturą - w sensie zdolności do jej tworzenia, przyswajania, akumulacji oraz nasycenia nią zarówno różnych dziedzin jednostkowego i zbiorowego życia, jak i węziej pojętej psychiki i osobowości - radykalnie odróżnia homo sapiens od świata rzeczy, roślin i zwierząt. Postępy badawcze oraz stale przyśpieszające przemiany cywilizacyjne postawiły jednakże liczne znaki zapytania nad tym tradycyjnym poglądem.

Komplikują bowiem ów pogląd obserwacje i badania, które stwierdzają, że zachowania i formy „kulturopodobne”, jak naśladowanie, uczenie się, zachowania adaptacyjne, emitowanie i odbiór sygnałów, znaków czy mowy oraz komunikowanie się partnerskie i zbiorowe występują nie tylko u ludzi, lecz także w świecie zwierząt, zwłaszcza u wyższych ssaków ${ }^{14}$. Toczy się zresztą długi spór o to, czy lub na ile zjawiska kulturowe i kulturopodobne w świecie ludzkim i zwierzęcym są w ogóle porównywalne ze sobą, do siebie podobne lub paralelne pod względem budowy, funkcji i stopnia rozwoju. Rzecz dotyczy więc ważnej z perspektywy kulturologii kwestii, czy i/lub jak dalece kultura zanurza się w naturze, wyłania się z niej albo tak czy inaczej w niej partycypuje. Innym kluczowym pytaniem jest z kolei to, czy zawdzięcza ona swe powstanie i rozwój tylko i wyłącznie człowiekowi,

${ }^{14}$ Liczne przykłady takich kulturowych lub quasi-kulturowanych zachowań zwierząt oraz argumenty za istnieniem i przeciw istnieniu kultury w tym świecie podają Kevin N. Laland i Bennett G. Galef we wstępie do redagowanej przez nich pracy zbiorowej The Question of Animal Culture, Cambridge, Mass 2009, tamże, Introduction, s. 1-18. http://static1.1.sqspcdn.com/static/f/1329369/17269756/1332457632513/ question_animal_culture.pdf?token [data dostępu: 13.10.15]. 
homo sapiens, czy też być może jest w tej lub innej proporcji wytworem powszechnej, trwającej miliony lat ewolucji form życia i gatunków ${ }^{15}$.

Przewartościowaniu ulega także stosunek kultury do „urzeczowionego”, mechanicznego i zautomatyzowanego świata techniki. Sugestywnie naświetlali ów problem dwaj niemieccy badacze:

Przenikanie w procesy kulturowe technicznych strategii, urządzeń, mediów i zestawów w coraz większym stopniu ukazuje kulturę (kultury) jako techniczny agregat, który w świetle zadań podejmowanych przez naukę nie odgranicza już dzisiaj nauk przyrodniczych od nauk o duchu (Geisteswissenschaften), rozumienia od wyjaśniania (Wilhelm Dilthey, Stephen Toulmin, Georg Heinrich von Wright) oraz inteligencji literackiej od technicznej (C.P. Snow), ze względu na sposób ich opisu. Tradycyjne nauki o duchu same przecież uciekają się w znacznym stopniu do wyjaśniających i technicznych procedur - chociażby w obrębie dyskursów i teorii medialnych - co powoduje, iż wspomniane rozróżnienia tracą ważność. Toteż neokantowskie, fundamentalne definicje nauk o kulturze, wywodzące się z początków XX wieku i reprezentujące ujęcia bipolarne, przestają na progu XXI wieku obowiązywać już jako teoretyczny punkt odniesienia" ${ }^{16}$.

Abstrahując w tym miejscu od złożonej, kontrowersyjnej problematyki teorii ewolucji i jej następstw, różnice świata ludzkiego i zwierzęcego przejawiają się, jak można sądzić, na kilka sposobów. Wyrażają się one jaskrawo przede wszystkim w tym, iż poszczególne dzieła i działy kultury - dotyczy to głównie epok historycznych posługujących się pismem - powstają w następstwie woli, zamiarów, świadomości, decyzji i umiejętności jednostek

${ }^{15}$ Tezę o bliskości świata ludzi i zwierząt i o ich zdolności do porozumiewania się formułował $\mathrm{z}$ pozycji biblijnych i chrześcijańskich w polemice $\mathrm{z}$ dziewiętnastowiecznymi naturalistami i ewolucjonistami Cyprian Norwid w późnym szkicu Ostatnia z bajek (1882).

${ }^{16}$ H. Böhme, K. Scherpe, Zur Einführung, [w:] Literatur und Kulturwissenschaft, red. H. Böhme, K. Scherpe, Hamburg 1996, s. 14-15. Obecność w kulturze medialnych środków technicznych umotywowała powstanie „medialnego kulturoznawstwa" jako osobnej, wyspecjalizowanej dyscypliny. 
lub zbiorowego wysiłku grup społeczności etnicznych i grup społecznych. $\mathrm{O}$ różnicy stanowi również uświadamiana oraz na rozmaite sposoby artykułowana w zachowaniach kulturowych historyczność kultury. W nowożytnych i nowoczesnych kulturach tworzy ona ich wewnętrzny komponent i rzutuje odpowiednio na wybory i zachowania kulturowe.

Innych przykładów kulturowej różnicy obu światów dostarczają odpowiednio literatura, sztuka, architektura, technika, rolnictwo, nauka. Wiele dzieł sztuki, literatury, filozofii czy nauki, podobnie jak szereg wynalazków, zastosowań i odkryć posiada bowiem charakter indywidualny, swoisty, osobowy i autorski. Wywodzą się one wprost z inicjatyw i wynalazczych działań jednostek i tylko pośrednio odnoszą się do odtwórczych zachowań i wzorów gatunkowych lub grupowych. Jeszcze inne z kolei zjawiska, jak uprawa roli, transport, architektoniczne, urbanistyczne czy przemysłowe przedsięwzięcia kulturowo-cywilizacyjne charakteryzują się w zestawieniu ze światem animalnym niewspółmiernie wielką skalą, rozmachem, złożonością i jakością. Wymagają one zbiorowej koordynacji, organizacji działań i skomplikowanych maszyn, które odzwierciedlają lub kształtują ludzką, zaawansowaną kulturę pracy.

Powyższe względy sprawiają, że trudno więc mówić o pełnej współmierności kultur ludzkiej oraz zwierzęcej. Należałoby natomiast rozróżnić elementarne, wąsko zakreślone enklawy mikro- lub minikultury świata zwierzęcego oraz rozbudowaną i skomplikowaną kulturę ludzką. Różnice skali, rozmachu i dokonań przechodzą tu w skokową różnicę złożoności, jakości i funkcji. Zamiast więc modernistycznych czy postmodernistycznych dążeń do utopijnego „uczłowieczenia” i „ukulturowienia” świata zwierzęcego przedmiotem refleksji (i troski!) powinny stać się raczej nierzadkie naturalistyczne przypadki i obrazy „zezwierzęcenia” dysponujących kulturą jednostek i społeczności ludzkich. Unaoczniają one luki w konstruktywnym, pozytywnym ukulturowieniu człowieka - w nasyceniu jego biosu 
humanistycznymi ideałami i normami - oraz potwierdzają istnienie zdegenerowanych, niszczycielskich wersji i wariantów kultury.

Należy jednak mieć na względzie również to, iż część zjawisk kulturowych bywa także wytworem sił i procesów anonimowych, działających albo w sposób przypadkowy, na zasadzie „ślepego zegarmistrza”, czy też bywa transmitowana i przyswajana niezauważalnie, czy funkcjonuje na poziomie nieświadomości lub podświadomości jednostkowej i zbiorowej ${ }^{17}$. Powoduje to, że w kulturze występują dzieła, normy lub rytuały nie wiadomo przez kogo, gdzie i kiedy stworzone oraz nie wiadomo skąd wzięte (folkor, przysłowia, mity, bajki i baśnie, zwyczaje, obrzędy). Ugruntowują one poglądy o normatywnym, bezosobowym i anonimowym charakterze kultury oraz o jej regulatywnym, systemowym działaniu, które nagina indywidualne inicjatywy i zachowania do systemowych reguł ${ }^{18}$. Właściwe romantykom pojmowanie kultury jako sfery wolności (improwizacji, inwencji, spontaniczności) znajduje tu kontrapunkt w stanowisku przyjmującym, odwrotnie, istnienie w niej norm, przymusów i konieczności, uzasadniających Freudowską wizję kultury jako represji i ,źródła cierpień”.

Anonimowość i nieznane pochodzenie tych czy innych artefaktów, norm, tabu czy rytuałów tłumaczą się po części tym, że niektóre z nich wywodzą się, jak dokumentuje to archeologia, z prehistorycznych i przedpiśmiennych epok paleo- i neolitu (czy nawet wcześniejszych), które przecież nie znały takich pojęć, jak autorstwo, jednostka, indywidualizm czy oryginalność, ukształtowanych historycznie i cywilizacyjnie stosunkowo niedawno. Wątpliwe też, czy były one zdolne do kulturowej refleksji bądź metarefleksji. Dystans czasowy jednakże sprawia, iż przedhistoryczni i przedpiśmienni wytwórcy narzędzi, broni, ornamentów i wisiorków, elementów stroju, naskalnych

${ }^{17}$ Culture and the Unconscious, red. C. Bainbridge, S. Radstone, M. Rustin, C.Yates, Oxford 2007.

${ }^{18}$ Podobne ujęcia wydają się charakterystyczne dla kulturologii radzieckiej i rosyjskiej lat 60. i 70. XX wieku. 
rysunków (petroglifów) czy kultowych figurek (jak postać Wenus z Tan-Tan znaleziona w Maroku lub Wenus z Berekhat Ram odkryta na Wzgórzach Golan $^{19}$ ), pozostają, jak neandertalczyk lub człowiek z Cro-Magnon, z natury rzeczy osobowo nierozpoznawalni i anonimowi. Wiele znalezisk archeologicznych jednak sugeruje, że to właśnie oni stopniowo tworzyli warunki umożliwiające powstanie relatywnie młodych - liczących bowiem zaledwie kilka tysięcy lat - społeczeństw historycznych dysponujących już stosunkowo rozwiniętymi zasobami artefaktów i wynalazków. Należały do nich na przykład podział pracy między mężczyzn i kobiety, organizacja zbiorowych działań, zasada podziału dóbr, pierwociny więzi rodzinnych, wytwarzanie odzieży, produkcja artystyczna, elementy rolnictwa oraz zakładanie czy budowa stałych osiedli itd. ${ }^{20}$

Powinno się ponadto uwzględnić to, iż niektóre zachowania kulturowe ulegają z czasem niezauważalnej naturalizacji, a ich konwencjonalna geneza zostaje zatarta, w rezultacie niemożliwa do rekonstrukcji i odczytania. To samo dotyczy wybiórczego, stale zmieniającego kierunek i punkt parcia funkcjonowania kulturowej pamięci zbiorowej. Wypadałoby zatem uznać hipotetycznie istnienie rozmaitych, głębinowych, „kopalnych” złóż kultury, czekających na odkrycie i identyfikację. Delimitacja kultury jest w tej perspektywie wpisanym w dzieje ludzkości procesem, który ma wzgląd nie tylko na istniejące, ustalone raz już granice, lecz musi liczyć się także z wytyczaniem w przyszłości rubieży nowych. Wynika to z obserwacji tego, jak funkcjonują poszczególne kultury. Stosują one zarówno zasady reprodukcji (powtarzania ustalonych wzorów i technik), jak i produkcji (twórczości),

${ }^{19}$ Badacze, nawiasem mówiąc, toczą spór o to, czy wspomniane figurki są rzeczywiście ludzkimi artefaktami, czy też uzyskały kształty antropomorficznie za sprawą przypadkowych procesów przyrodniczych.

${ }^{20}$ J.A. Mears, Integrating Prehistory into the Study Humanity's Common Past, [w:] Teaching World History: A Resource Book, red. H. Roupp, Londyn 2015, s. 82. 
która uwzględnia nowe idee i potrzeby, wynalazki, nieznane dotąd techniki, zasoby energii, materiały oraz zmieniające się warunki.

Okoliczności te uzmysławiają, że brak lub niedostatek wiadomości o wytwórcach i użytkownikach archaicznych artefaktów, okolicznościach, technikach czy metodach ich wytwarzania i o rzeczywistych funkcjach w pierwotnych wspólnotach nie świadczy bynajmniej o tym, że wzięły się one znikąd. Nie dowodzi również, że takich pradawnych twórców, użytkowników lub wspólnot w ogóle nigdy nie było. To samo stosuje się do zamierzchłych procesów kulturowych, które już definitywnie ustały. Niewiedza czy też białe plamy nie uzasadniają zatem kategorycznego twierdzenia, że funkcjonowanie kultury cechują anonimowość, ,wieczne archetypy”, inercyjne przymusy systemowe lub nieuświadamiane naciski urazowe, rodzące zakonspirowane traumy niemożliwe do przełamania.

Delimitację komplikują także dwie biegunowo różne dyspozycje. Tworzy je, z jednej strony, zdolność danej kultury do asymilowania nabytków wywodzących się z innych kultur, z drugiej zaś, przeciwnie, zdolność do stawiana oporu wobec promowanych lub narzucanych wzorów, zachowań, artefaktów, instytucji czy nawyków. Oferuje się je zazwyczaj w zamiarze zastąpienia form miejscowych obcymi, przestarzałej obyczajowości nowoczesną, wiejskiej miejską itp. Znamienne, że opór wobec kultury narzucanej częstokroć wyraża się przewrotnie w spotęgowanej afirmacji kultury rodzimej, także w sytuacji, gdy posiada ona oczywiste niedostatki i zdradza dysfunkcje. Przykładem może być kultura sarmacka w konflikcie z oświeconą „francuszczyzną” i szerzej, „cudzoziemszczyzną”. Nie podobna jednakże określonej kulturze przypisać zawsze tych samych i takich samych tendencji, a jednocześnie stawiać uogólniających diagnoz na podstawie bieżących obserwacji. Równie dobrze może ona wykazywać niechęć do innowacji i skłonność do zastoju, jak też charakteryzować się otwartością, chłonnością i elastycznością. Możliwości takie tkwią wewnętrznie w jej instrumentarium i repertuarze, aczkolwiek o ich użyciu stanowią jej nosiciele. 
Świadczy to w efekcie o tym, iż kultury jako takiej nie sposób utożsamić w pełni ani z psychologią jednostkową lub zbiorową, ani z etnosem, ani ze statusem społecznym, ani z kondycją polityczną. Jest ona bowiem wartością wyuczoną, której stan (użycie) zależy od konkretnych zewnętrznych okoliczności, potrzeb, warunków bytowych lub społecznego usytuowania i zakorzenionych nawyków nosicieli. Ta sama kultura może więc cechować różne warstwy socjalne i odwrotnie, przedstawiciele tej samej warstwy mogą reprezentować różne kultury.

Nasuwa to wniosek, iż relacja między kulturą a jej ludzkim zapleczem etnicznym lub społecznym bywa dynamiczna. Kultura, która podlega wewnętrznym przeobrażeniom i uczestniczy $\mathrm{w}$ interakcji $\mathrm{z}$ innymi kulturami, reaguje także na przesunięcia i zmiany w tym zapleczu oraz niekiedy sama je inicjuje. Uzmysławia nam to, że przywoływana w badaniach ,jedność” kultury powszechnej jest pojęciem bardziej teoretycznym i postulatywnym niż opisowo-referencyjnym. U podstaw owej sugerowanej jedności znajduje się bowiem niezaprzeczalna realna wielość i różnorodność kultur ${ }^{21}$. Dążenie do koordynacji obu tych polarnych twierdzeń odzwierciedla swoistą pozycję teoretyczną kulturologii: z jednej strony, właściwą dla niej tendencję generalizującą i nomotetyczną, połączoną jednakże, z drugiej strony, z respektowaniem stającej się i zróżnicowanej rzeczywistości kulturowej.

W kwestii różnorodności jest tu jednakże konieczne zastrzeżenie. Otóż wielość i różnorodność kultur nie oznacza bynajmniej ich nierówności.

${ }^{21}$ Różnorodność tę Claude Lévi-Strauss wyjaśniał tym, iż naturę ludzką charakteryzuje to, co w przyrodzie uniwersalne, podczas gdy ludzkimi zachowaniami rządzą z kolei rozmaite partykularne i personalne reguły, które wynikają z istnienia rozmaitych kultur. Powodują one, że postawy, zachowania i wybory ludzkie rozmijają się pod względem pożywienia (kuchni), ubierania się, wyrażania uczuć, moralności, rozumienia dobra i zła, postrzegania i oceny innych, odmiennego interpretowania wydarzeń itp. Wyróżnikiem człowieka w konfrontacji z naturą jest tedy to, iż cechuje go „zmienność kulturowa” (la variabilité culturelle), zob. G. Charbonnier, Entretiens avec Claude Lévi-Strauss, Paryż 1969. 
Założona u podstaw kulturologii idea jedności kultury zwraca się natomiast polemicznie przeciwko dyskryminującym i restrykcyjnym podziałom kultur na niższe i wyższe, lepsze i gorsze, wysublimowane i barbarzyńskie itp. Przez podobne podziały są inspirowane teorie i praktyki rasistowskie, etnocentryzm, nacjonalizm ${ }^{22}$. Przeciwstawiając się tego rodzaju poglądom, kulturologia uznaje istnienie wielu różniących się, lecz zarazem równorzędnych kultur, które tak czy inaczej oddziałują na siebie, przenikają się oraz wymieniają się wzorami i wartościami.

Zasadzie różnorodności i równorzędności kultur przeczą, zdawałoby się, poglądy eksponujące zjawiska trwałego dziedziczenia jednej i tej samej kultury przez społeczności etniczne, społeczne lub religijne. Towarzyszy temu stanowisku sugestia, iż kultura określa z tego tytułu „trwałe” lub zgoła „niezmienne" cechy danej społeczności. Przeocza się lub pomija tutaj jednakże to, że dziedziczenie nie oznacza mechanicznej reprodukcji i unieruchomienia. Dokonują się w nim bowiem nieprzerwane historyczne przewartościowania i przemiany, często mikroskopijne i trudno zauważalne. Następują one również pod wpływem otoczenia: ingerencji, transferów i oddziaływań innych społeczeństw i ich kultur. Toteż twierdzenia o „dziedzicznej trwałości” i „niezmienności” czy to danej kultury, czy to danej społeczności zawężają horyzont historii do spełnionej i unieruchomionej przeszłości, ignorują zaś otwartą i niosącą niespodzianki przyszłość. Słowa poety: „,- O! Nie

${ }^{22}$ Istotą etnocentryzmu jest to, iż traktuje on własne społeczeństwo i własną kulturę jako nieprześcigniony wzór dla innych i postrzega każde odstępstwo od tego wzoru jako znak niższości. Tymczasem dana społeczność i jej kultura uznają i głoszą swoją wyższość jedynie na podstawie wymyślonego przez siebie kryterium, które nie jest wszakże bardziej miarodajne niż takież kryteria proponowane przez pozostałe społeczności i kultury. „Wyższość” reklamującej się kultury jest więc nie do udowodnienia. Sprawia to, że etnocentryzm nie ma realnych podstaw i jest $w$ istocie zbiorowym solipsyzmem, roszczeniem i pretensją. 
skończona jeszcze Dziejów praca"23 powinny być tu przestrogą i nauką dla wszystkich, którzy pochopnie utożsamiają kulturę z dziedziczeniem.

Specyfika poszczególnych kultur zawiera się zatem w tym, iż tworzą one kompozycję różnorodnych składników, podczas gdy na różnorodny kształt całości składają się z kolei różne ze swej istoty poszczególne kultury. Taki stan rzeczy zaświadcza swoją obecność zarówno w synchronii, jak i w diachronii. Krzewi się dzięki wewnętrznemu przeobrażaniu i różnicowaniu kultur, zastępowaniu schodzących ze sceny dziejowej wchodzącymi, wypieraniu pokonanych przez dominujące, tradycjonalnych przez nowoczesne, klasycznych przez hybrydyczne. Powstawaniu i utrzymywaniu się różnorodności sprzyjają na równi: konserwowanie tradycji, akty zapożyczeń, wymiany kulturowej i dialogu. Warunkiem rzeczywistej różnorodności jest bowiem każda „odmienność” lub „inność”, albowiem zawsze przeciwdziałają one entropii. Służyło jej na przykład w makroskali historycznej wypieranie politeizmu przez monoteizm, upoetyzowanego etosu rycerskiego przez trywialne stosunki i upodobania mieszczańskie, indiańskich wigwamów przez stylizowane, murowane rezydencje plantatorów, powozu przez samochód, łuczywa przez świecę i lampę naftową, energii wodnej przez atomową itd.

W tym sensie indywidua i społeczności nie są zdeterminowane przez jednolity i utrzymujący się typ kultury, trwale im przypisany, niewrażliwy na przemiany istniejących stosunków i warunków. Istnienie wzmożonej kontroli ustrojowej (na przykład jawnej lub ukrytej cenzury) nie wyklucza bowiem bez reszty wprowadzania do panującego systemu kulturowego choćby ograniczonych innowacji, dokonywania w nim przetasowań i przewartościowań oraz uzupełniania go zapożyczeniami. Historyczne przykłady dowodzą, że nawet najbardziej szczelne systemy ustrojowe (państwa totalitarne!) okazują się w tych czy innych dziedzinach przenikalne i nieszczelne. Badacz

${ }^{23}$ Cyprian K. Norwid, Pisma wszystkie, t. 2, Warszawa 1971, s. 19. 
wczesnych chińskich wpływów intelektualnych w Europie charakteryzował rzecz następująco:

[...] nigdy nie było w dziejach na tyle autonomicznej cywilizacji, która okazałaby się zdolna do ciągłego rozwoju w granicach politycznej lub ekonomicznej autarkii. [...] [A]by zaznać dłuższej, udanej ery pokoju i prosperity, cywilizacje muszą sięgać do użytecznej wiedzy wywodzącej się z centrów innych cywilizacji.

W przyrodzie bowiem, podobnie jak w historii nie może być wiedzy bez kontaktów - wiedza ludzka odradza się bowiem nieprzerwanie właśnie za pośrednictwem kontaktów, zawsze się zmienia, zawsze ewoluuje ku coraz większej złożoności ${ }^{24}$.

\section{Akceleracja, piśmienność, wielokulturowość, kulturalizm}

Rzecz zawiera się jednakże w tym, iż kultury akumulują dorobek przeszłości i że u ich źródeł tkwią - nie zawsze zresztą widoczne dla nieuzbrojonego oka - uprzednio ukształtowane i przyswojone doświadczenia, umiejętności i tradycje, które z czasem wprawdzie ulegają modyfikacji i dostosowują się do zmieniających się warunków, ale stawiają zarazem opór arbitralnym i woluntarystycznym innowacjom. Można by zasadnie przyjąć, iż w skali historycznej i globalnej - operowanie taką skalą umożliwiły nowoczesne procesy cywilizacyjne, a zwłaszcza intensywny rozwój wymiany, komunikacji i zagęszczenie sieci informacyjnych - kultura akceleruje samą siebie. Wchłania i przepracowuje dorobek epok poprzednich, a jednocześnie wyzwala się od ich uzależniającego wpływu. Pierwiastki dziedziczenia, transmisji oraz inwencji i nowatorskich inicjatyw konkurują tu ze sobą oraz wzajemnie się przenikają. Ciągłość, recycling i rewriting, interakcja, akty zerwania i zwroty kulturowe kształtują, jak obrazują to dzieje kultury, jej

${ }^{24} \mathrm{Ch}$. Gerlach, Wu-Wei in Europe. A study of Eurasian economic thought, Londyn 2005. Cyt. wg http://eprints.1se.ac.uk/22479/1/wp12.pdf [data dostępu: 26.10.15] 
współczesną, przyśpieszoną dynamikę, która rozsadza dotąd istniejące ramy i wzorce.

Przedmiotem zainteresowania kulturologii są w efekcie nie tylko specyfika, wyznaczniki i wewnętrzne powiązania zjawisk kulturowych, lecz także - wspominałem o tym w innym kontekście - ich stawanie się i przemiany. Kulturologia, która koncentrowałaby się na statycznych ze swej istoty relacjach systemowych i pomijałaby te ostatnie, szybko okazałaby się zapóźniona i bezużyteczna.

Prawdą jest jednak, że nie brakuje współcześnie opinii, które podkreślają idiomatyczność, nieporównywalność i zamkniętość poszczególnych kultur, zwłaszcza geograficznie oddalonych, pozbawionych przez długi czas interakcji i wspólnej historii, rozleglejszych kontaktów handlowych, wymiany i żywszych więzi z kulturami innych kontynentów. Wskazuje się tu na dystans oraz odmienność wzorów kulturowych i tradycji, w tym laickiej, racjonalistycznej kultury Zachodu (Europy) oraz pojęć, wyobrażeń i wierzeń Dalekiego Wschodu. Jak zatem uzgodnić na przykład Biblię lub zachodnią świecką myśl naukową z szintoizmem, konfucjanizmem, taoizmem, buddyzmem czy hinduizmem? Jaką miarą mierzyć różne systemy społeczne i polityczne Wschodu i Zachodu? I vice versa: jak oswoić Zachód, dajmy na to, z chińską organizacją przestrzeni feng shui lub taoistyczną filozofią i etyką zwaną $w u$ wei ${ }^{25}$ ?

Gdyby więc założyć, jak postulują niektórzy współcześni badacze, którzy nawiązują do idei Thomasa Kuhna i Paula Feyerabenda, zasadniczą niewspółmierność kultur (systemów kulturowych) ${ }^{26}$ - a więc ich wewnętrzną nieprzenikalność, nieprzetłumaczalność, zamkniętość, rodzaj trwałego „zabetonowania" - stałyby się one dla ich nosicieli barierami hamującymi zarówno

${ }^{25}$ Zasady i zastosowania wu wei omawia Edward G. Singerland, Effortless Action: Wu-wei as Conceptual Metaphor and Spiritual Ideal in Early China, Oxford 2003.

${ }^{26} \mathrm{~J} . J$. Alarcón, Anthropology. Indeterminacy and Incommensurability, http://hottopos.com/convenit6/jareno.htm [data dostępu: 10.10.15]. 
porozumiewanie się i wymianę z zewnętrznym otoczeniem, jak i własny ruch i rozwój. Sprzyjałyby bezproduktywnym ograniczeniom ${ }^{27}$. Aby uniknąć podobnych następstw, dana kultura - działając zresztą niejako we własnym interesie - musi (czy też powinna) uwzględniać i wydobywać w swym funkcjonowaniu czynniki inicjatywy, inwencji i swobody oraz uczestniczyć w wymianie kulturowej, a w następstwie akceptować wprost lub dyskretnie transfery i zapożyczenia międzykulturowe. Kulturologia uznaje tego rodzaju

${ }^{27}$ Przytaczam tu $\mathrm{w}$ oryginale in extenso głośny, często cytowany argument Hilarego Putnama skierowany przeciwko tezom o niewspółmierności: „The incommensurability thesis is the thesis that terms used in another culture, say, the term 'temperature' as used by a seventeenth-century scientist, cannot be equated in meaning or reference with any terms or expressions we possess. As Kuhn puts it, scientists with different paradigms inhabit 'different worlds'. [...] The rejoinder this time is that if this thesis were really true then we could not translate other languages - or even past stages of our own language - at all. And if we cannot interpret organisms' noises at all, then we have no grounds for regarding them as thinkers, speakers, or even persons. In short, if Feyerabend (and Kuhn at his most incommensurable) were right, then members of other cultures, including seventeenth-century scientists, would be conceptualizable by us only as animals producing responses to stimuli (including noises that curiously resemble English or Italian). To tell us that Galileo had 'incommensurable' notions and then to go on to describe them at length is totally incoherent.” [„,Teza o niewspółmierności mówi o tym, że pojęcie użyte w innej kulturze, powiedzmy pojęcie »temperatury «, stosowane przez siedemnastowiecznego naukowca, nie może być utożsamiane w znaczeniu czy odniesieniu z jakimkolwiek pojęciem lub wyrażeniem, jakim operujemy. Zdaniem Kuhna, naukowcy z różnymi paradygmatami zamieszkują „różne światy”. [...] Jeśli ta teza by była prawdziwa, to zupełnie niemożliwe byłoby thumaczenie innych języków - ani nawet wcześniejszych stadiów naszego własnego języka. A jeśli nie możemy interpretować dźwięków organizmów, to nie mamy podstaw ku temu, by traktować te organizmy jako istoty myślące mówiące, a nawet jako istoty ludzkie. W skrócie, jeśli Feyerabend (i Kuhn w swojej największej niewspółmierności) mieli rację, to wtedy członkowie innych kultur, w tym siedemnastowieczni naukowcy,, mogliby być konceptualizowani przez nas tylko jako zwierzęta produkujące reakcje na bodźce (w tym dźwięki dziwnie przypominające angielski lub włoski). Mówienie nam, że Galileusz miał »niewspółmierne« pojęcia, po to, by następnie przejść do ich szczegółowego opisu jest całkowicie niespójne" - tłum. M.C.]. Cyt za: H. Putnam, Reason, Truth and History, Cambridge 1981, s. 114-115. 
procesy za warunek i czynnik rozwoju kultury. Działania w tym kierunku stały się zresztą jednym z kanonów polityki kulturalnej, aczkolwiek, warto zauważyć, akceptowanym nierzadko z oporami i ograniczeniami. Rodzi je masowy napływ nosicieli cudzej (,obcej”) kultury, który zagraża ustabilizowanej, dominującej dotąd pozycji kultury miejscowej.

Wyzwanie dla teorii o niewspółmierności i nieprzetłumaczalności kultur stanowi praktyka kulturowej piśmienności (cultural literacy), stymulowana przez migracje i kontakty międzykulturowe. W rozszerzonej interpretacji odnosi się owa ,piśmienność” nie tylko do języka artykułowanego i literatury, lecz także do całego obszaru danej kultury, w tym do artefaktów oraz do zachowań, obyczajów czy rytuałów ${ }^{28}$. Wydobywa tkwiący w tych ostatnich potencjał intelektualny, słowny, znakowy, symboliczny oraz tekstowy (dyskursywny). Stanowiąc analogię do piśmienności lingwistycznej i literackiej, polegającej na umiejętności czytania, pisania i komunikowania się za sprawą znajomości alfabetu, słownika i gramatyki - a w konsekwencji na wprawie w redagowaniu i odbiorze komunikatów w cudzym języku - piśmienność kulturowa, którą niesłusznie sprowadza się niekiedy do erudycji, przejawia się z kolei w opanowaniu kodu, reguł i konwencji cudzej kultury oraz w efektywnym porozumiewaniu się z jej nosicielami i reprezentantami. Przenosi się to również na znajomość preferowanego w niej sposobu życia, orientację w „wielkich narracjach” i anegdotach cudzej kultury, formach

${ }^{28}$ James Gee określa piśmienność kulturową jako umiejętność operowania w otoczeniu społecznym dyskursami, które kojarzą ,język, myślenie i działanie”, zob. tegoż, What is Literacy?, [w:] Candace Mitchell, Kathleen Weiler (red.), Rewriting Literacy: Culture and the Discourse of the Other, New York 1991, s. 3. Koncepcję tę rozwinął William T. Fagan, Literacy and Cultural Thoughtfulness: the Power and Helplessness within and beyond Cultural Boundaries, http://www.literacy.org/ sites/literacy.org/files/publications/fagan_cult_lit_prac_in_Canada_96.pdf [data dostępu: 25.10.15]. Ujął on piśmienność jako kompetencję kulturową umożliwiającą komunikacyjne i behawioralne przechodzenie od prymarnego kontekstu kulturowego do kontekstów rozszerzonych. 
rozrywki, wzorach ekspresji, idiomach, idiosynkrazjach, aluzjach kulturowych i historycznych, topografii itp. Stosuje się ona zarówno do kultury wysublimowanej (,wysokiej”), jak i do zachowań powszednich (powitań, pozdrowień, etykiety, ubioru, posiłków, wspólnej zabawy, rozumienia symboli itd.). Efektem piśmienności tego typu bywa więc kształtowanie uniwersum dyskursu wspólnego dla odmiennych kultur, osłabiającego granice i - zdawałoby się - niemożliwe do pokonania bariery komunikacji.

Piśmienność kulturowa stanowi konsekwencję wielokulturowości (multikulturalizmu) oraz nasilających się wzajemnych oddziaływań międzykulturowych (interkulturalizmu), a zarazem katalizator pobudzający rozwój tych procesów. Istotę ich tworzą bowiem kontakty, przenikanie się (przemieszanie) oraz interakcja nosicieli odmiennych kultur, a w rezultacie samych tychże kultur. Procesy tego rodzaju - nie zawsze przecież akceptowane z perspektywy etnocentryzmu i ideału państwa narodowego - sprzyjają zarówno otwieraniu się na cudze kultury i asymilowanie ich kodów, jak i umożliwiają transfer kodów własnych, a w następstwie oddziaływanie na nie w tej czy innej dziedzinie. Te trzy zjawiska - piśmienność kulturowa, wielokulturowość i interakcja kultur - odzwierciedlają bez wątpienia doniosłe współczesne procesy kulturowe, które modyfikują wiele tradycyjnych, często przestarzałych wyobrażeń o kulturze i z tego względu nie mogą być wzięte w nawias i wykluczone z pola widzenia kulturologii.

Piśmienność kulturowa, zahaczona o wielokulturowość i interakcję kultur, stymuluje zatem pogłębione, autentyczne obcowanie z kulturami innymi niż własna, a jednocześnie umożliwia spojrzenie na kulturę własną z pozycji „bycia poza nią” i przyjrzenia się jej w lustrze innych kultur - a więc niejako z perspektywy kogoś innego, dysponującego innym kodem kulturowym (lub innymi kodami), postrzegającego oraz modelującego rzeczywistość (i ewentualnie) własną egzystencję według innych niż dotychczas reguł. Daje to możliwość zaktualizowania i przewartościowania poszczególnych aspektów kultury własnej, uświadomienia sobie jej ewentualnych luk oraz próby ich 
uzupełnienia ${ }^{29}$. Taka postawa inności (i swego rodzaju wyobcowania) wobec samego siebie mogłaby na pierwszy rzut oka wydać się utopijna, niemożliwa do realizacji, podczas gdy w rzeczywistości stanowi ona warunek kulturowej transgresji, wyjścia z etnolingwistycznej monokultury i uprawiania dialogu. Daje sposobność odnowy i zróżnicowania repertuaru kulturowego.

Wspomniana metamorfoza służy również budowaniu płaszczyzn porozumienia między różnymi kulturami oraz ich wymianie. Negatywnej i paraliżującej tezie o niewspółmierności, nieporównywalności i nieprzekładalności poszczególnych kultur przeciwstawia kulturologia alternatywny - wsparty historycznymi badaniami porównawczymi - obraz ich chronicznej niedomkniętości, niesamowystarczalności i niezupełności, obligujący do kontaktów oraz wymiany z otoczeniem kulturowym. Przykład (i wzór)

${ }^{29}$ Modelem postawy i strategii tego typu pozostaje egzystencjalna i epistemologiczno-ontologiczna idea „wnienachodimosti” (ros. вненаходимость; ang. outsidedness lub outsideness) zarysowana we wczesnych pracach Michaiła Bachtina. Polega ona na wydobyciu kardynalnej percepcyjnej różnicy w postrzeganiu samego siebie oraz innego. Różnica ta wyraża się w tym, iż jednostka (lub podmiot zbiorowy) - nie jest w stanie określić poznawczo samej siebie z zewnątrz równie wszechstronnie jak kogoś innego. Uniemożliwia to cielesne usytuowanie oka ogarniającego to, co ,przed sobą" lub ,z boku”, a nie zaś to, co „, tyłu”, „za sobą”. Toteż spojrzenie takie charakteryzuje swoisty „,nadmiar widzenia” względem innego, a jednocześnie „niedostatek” widzenia w stosunku do samego siebie. Ten niedostatek widzenia siebie z zewnątrz i nadmiar wobec innego ma z kolei swój odpowiednik w nadmiarze wewnętrznej, płynnej, pozbawionej konturów samoobserwacji (introspekcji) danego podmiotu oraz w niedostatku wiedzy o rzeczywistości wewnętrznej innego. Podobna sytuacja poznawcza umożliwia podmiotowi względne wniknięcie w innego za sprawą transgresji oraz powrót do siebie wraz ze zdobytą wiedzą o innym, sobie samym i relacji z innym - bez konieczności rezygnowania z własnego punktu widzenia i stanowiska światopoglądowego. Powrót taki stanowi warunek konstruktywnego dialogu z innym, rozszerzającego horyzonty (pole widzenia, język, krąg wartości) obu stron. Zob. Татьяна М. Обухова, «Вненаходимость» в диалоге культур (по работам М.М Бахтина), [w:] Языки. Культуры. Перевод. Материаль международного научно-практического форума, Москва 2013, s. 369-379 oraz Г.В. Дьяконов, Диалогийная концепщия эстетики и литературоведения М.М. Бахтина, [w:] „Социальна психология” 2006, № 6 (20), s. 35-46. 
piśmienności literackiej węższej niż kulturowa okazuje się w tej dziedzinie szczególnie użyteczny. Unaocznia on, iż we współczesnej cywilizacji literatura bodajże w każdym ze znanych języków etnicznych uczestniczy w procesie translacji na inne języki. Podlega ona tym samym z natury rzeczy podwójnej transgresji. Dokonuje się dzięki thumaczeniu i przyswajaniu dzieł reprezentujących cudze języki i cudzą literaturę, które ewentualnie zapoczątkowują lub utrwalają takie czy inne zmiany w literaturze rodzimej, a w każdym razie poszerzają jej widzenie rzeczywistości. Inną formą transgresji stają się z kolei thumaczenia literatury rodzimej na inne języki. Dana literatura wykracza tu poza granice rodzimego języka etnicznego i systemu literackiego oraz wtapia się w nowe otoczenie. Ilustracją mogłaby być międzynarodowa recepcja dzieł Szekspira, współcześnie zaś - takaż recepcja laureatów literackiej Nagrody Nobla. W obu tych wypadkach transgresja i translacja stymulują proces literacki. W tej sytuacji samowystarczalność, izolacja i zasklepienie literatury (bądź kultury) w sobie samej - bez względu na to, czy byłyby one wymuszone lub sterowane przez instancje z zewnątrz (na przykład przez władzę, ideologię, religię lub tradycję), czy też byłby to efekt zawyżonej samooceny - równałyby się martwocie i zastojowi literatury. Paralelizm kultury w tym względzie nasuwa się sam przez się - pod warunkiem, że pojęcie translacji literackiej uzupełnimy pojęciami translacji interartystycznej oraz interkulturowej (intersemiotycznej) ${ }^{30}$.

Na przeciwnym biegunie do poglądu o selektywnym, zamkniętym i nieprzenikalnym dla odmiennych wartości kręgu kulturowym sytuuje się pod pewnymi względami koncepcja tak zwanego kulturalizmu. Otóż kulturalizm głosi wszechprzenikalność i wszechobecność kultury we wszystkich aspektach życia i kwestionuje tym samym zdolność do zajęcia wobec niej zewnętrznego, zdystansowanego stanowiska. Podważa zdolność jednostkowego lub

${ }^{30}$ S. Faiq, The Discourse of Intercultural Translation, „Intercultural Communication Studies" 2004, XIII, s. 3. 
zbiorowego - etnicznego lub społecznego - podmiotu do niezależnej i samodzielnej jej oceny, więcej: do wyboru, modyfikacji i kształtowania według kryteriów innych niż wypływające z niej samej. Przeczy możliwości występowania niezależnych od niej postaw i preferencji oraz możności podejmowania inicjatyw i dokonywania innowacji. $Z$ góry wyklucza sprzeciw i stawianie oporu nieodpartej, naciskającej z zewnątrz i od wewnątrzkulturowej Wille zur Macht.

Przyjmuje się tu zatem, iż zjawiska kultury wynikają z innych zjawisk kulturowych (,same z siebie”) i że stygmatyzują one wszelkie przejawy ludzkiego życia i ludzkiej działalności. Także samo poznanie kultury jest w świetle ekspansywnego kulturalizmu uwarunkowane przez kulturę (klarownie unaocznia to istnienie błędnego koła w myśleniu kulturologicznym). W jej zasięgu i pod jej wpływem znajduje się więc religia, nauka, polityka i ekonomia. Kulturalizm wyróżnia i akcentuje bowiem w tych dziedzinach wszystko to, co zbieżne z kulturą, zaciera lub ignoruje natomiast przejawy odrębności i różnice. Absolutyzuje w rezultacie jawnie lub skrycie zasadę kulturowego samorództwa (generatio spontanea).

Pogląd ten stawia jednostkę, społeczność oraz kulturę w jaskrawej opozycji do natury. Postrzega w ostatniej instancję coraz mniej wpływową i coraz słabiej oddziałującą na przestrzeń kulturowo i cywilizacyjnie zagospodarowywaną. Wskazuje jednocześnie na stale postępujące wypieranie natury i na nieodwracalne wyobcowanie z niej istot i społeczności ludzkich. Idę człowieka jako biologicznej cząstki natury - w tym również roussoistyczną utopię szlachetnego dzikusa - wyznawcy kulturalizmu zastępują antropologiczną koncepcją postrzegającą w nim twórcę i nosiciela kultury, bez reszty przez nią określanego, stanowiącego jej nierozłączną część. Naturze przyznano z kolei właściwości tworzywa, obrabianego i przekształcanego według aktualnych potrzeb i wzorów, zamienianego następnie w artefakty, wprowadzane w kulturowe obiegi, które wyznaczają z kolei granice, ramy i przestrzeń jednostkowej i społecznej egzystencji. 
Kulturalizm sankcjonował również koncepcje postrzegające w kulturze system znaków, symboli, znaczeń oraz tekstów wszelkiego rodzaju. Utożsamiał ją z ,semiosferą”. Przyznawał konkretnym systemom (i podsystemom) znakowym oraz kompleksom tekstów kulturowych prymat zarówno w stosunku do zjawisk przyrodniczych, jak i społecznych ${ }^{31}$. Określały one sposoby identyfikacji i samoidentyfikacji członków społeczności, tradycję i wzajemne porozumiewanie się członków. Umożliwiały kontakty z innymi społecznościami. Współtworzyły też modele świata, pozwalające interpretować otaczającą rzeczywistość oraz praktycznie się w niej orientować.

Semiotykę kultury, warto podkreślić, formułowali badacze z różnych krajów, by wspomnieć tylko Ernesta Cassirera, autora Philosophie der Symbolischen Formen (trzy tomy, 1923-1929), Claude'a Lévi-Straussa, inicjatora antropologii strukturalnej i autora pracy Anthropologie structurale (1958) lub Jurija Lotmana, autora zbioru rozpraw Статьи по типологии культуры: Материалы к курсу теории литературы (1970). Myśli tego typu podejmował i rozwijał - w szczególności na gruncie amerykańskim - Clifford J. Geertz w pracy The Interpretation of Cultures (1973), zbierającej wcześniejsze szkice i rozprawy (przekład polski: Interpretacja kultur. Wybrane eseje, 2005). William H. Sewell następująco uogólniał wspomniane stanowisko (przytaczam tę wypowiedź w oryginale):

What all of these approaches had in common was an insistence on the systematic nature of cultural meaning and the autonomy of symbol systems - their distinctness from and irreducibility to other features of social life. They all abstracted a realm of pure signification out from the complex messiness of social life and specified its internal coherence and deep logic.

${ }^{31}$ Spojrzenie na kulturę jako system znaków oraz procesów komunikowania się rozszerza niekiedy jej granice poza krąg ludzki i przenosi je w świat zwierząt, roślin i maszyn, a nawet, jak sądzili romantycy, w świat duchów i upiorów. 
Their practice of cultural analysis consequently tended to be more or less synchronic and formalist ${ }^{32}$.

Nie wydaje się jednak, by poglądy tego rodzaju ostawały się współcześnie krytyce. Akcentując jednorodny charakter i spoistość systemu, z jednej strony izolują i usamodzielniają one kulturę, wyjmują ją z historycznych i społecznych kontekstów, abstrahują nie tylko od zewnętrznych uwarunkowań, oddziaływań i wpływów, lecz także od wewnętrznych zaburzeń i przekształceń. Oczyszczają ją w następstwie $\mathrm{z}$ heterogenicznych domieszek oraz sztucznie upraszczają i ujednolicają. W tym duchu rozwijały się na przykład poglądy moskiewskiej i tartuskiej szkoły lingwistyczno-semiotycznej. ,[...] [K]ultura, pisał J. Lotman w rezonującym stylu lat 1970., nigdy nie reprezentuje uniwersalnego zbioru (универсального множества), a tylko pewien zorganizowany w określony sposób podzbiór. Nigdy też nie obejmuje wszystkiego [kursywa J.L.], tworząc jedynie w pewien szczególny sposób odgrodzoną sferę. Kultura funkcjonuje zatem tylko jako wydzielona część (участок), jako zamknięty [! - E.K.] obszar na kanwie nie-kultury"33. Symptomatyczne w tym ujęciu pozostaje niezróżnicowane i negatywne pojęcie ,nie-kultury”.

${ }^{32}$ [,Wszystkie te podejścia łączył nacisk na systematyczny charakter znaczenia kultury i autonomię systemów symbolicznych - a także ich odrębność od innych cech życia społecznego i nieredukowalności do nich. Wszystkie wydobywały czyste znaczenia z zawiłego nieładu życia społecznego, jak również określały jego wewnętrzną spójność i głęboką logikę. Ich praktyka analizy kulturowej była w zasadzie konsekwentnie mniej lub bardziej synchroniczna i formalistyczna" - tłum. M.C.], W.H. Sewell, The Concepts of Culture, [w:] Beyond the Cultural Turn .New Directions in the Study of Society and Culture, red. Victoria E. Bonnell, Lynn Hunt, Berkeley 1999, s. 51.

33 J. Lotman, O семиотическом механизме культуры (1971), [w:] tegoż, СЕМИОСФЕРА. Культура и взрыв. Внутри мыслящих миров. Статьи. Исследования. Заметки (1968-1992), Sankt Petersburg 2000, s. 485. Cyt. za: http://yanko.lib.ru/books/cultur/lotman_semiosphera.htm, [data dostępu: 11.10.15], s. 352 . 
Z drugiej zaś strony, koncepcje, które postrzegają kulturę jako nieprzenikalny, ,zamknięty system”, utożsamiają ją implicite z reprodukcją zastanych artefaktów, norm, wzorów i wartości. Wikłają w ten sposób określenie kultury w regressus ad infinitum. Stanowisku temu przeczy jednakże empiryczna różnorodność, zmienność oraz kreatywny (innowacyjny) charakter poszczególnych zjawisk, dzieł, form i procesów kulturowych. Toteż badaczka niemiecka Doris Bachmann-Medick nie bez racji zauważyła, iż „kulturalizm oznacza hipostazowanie tego, co kulturowe, pomijanie władzy, dynamiki materialnej i społecznej, polityki i ekonomii" ${ }^{34}$.

Podsumujmy. Ujmując rzecz z perspektywy kulturologii, nie sposób utożsamić kultury ani wyłącznie z trwaniem, ani też z jej lotną zmiennością form; ani z reprodukcją gotowych wzorów, ani z gorączkowym tworzeniem nowości. Cechuje ją bowiem i jedno, i drugie: trwanie i zmienność; reprodukcja i kreatywność. Rzadko tkwiąc w zamkniętym, systemowym porządku, wchłania i adaptuje ona pierwiastki spoza rodzimego kręgu. Dokonuje też recyclingu ogniw zdezaktualizowanych i zużytych. Jej odmiany i odnogi („podsystemy”) znamionuje względna przekładalność, możliwa za sprawą znaków, symboli i znaczeń. Dopuszcza enklawy idiolektu i hermetyzmu, które kultywują z kolei „sekretny” charakter znaków i form, ezoteryzm, „,ciemność mowy” czy łamanie norm ${ }^{35}$.

34 D. Bachmann-Medick, Kulturanthropologie, [w:] Konzepte der Kulturwissenschaften. Theoretische Grundlagen - Ansätze - Perspektiven, red. Ansgar Nünning, Vera Nünning, Stuttgart 2003, s. 102. Zob. także W. Kaschuba, Kulturalismus. Vom Verschwinden des Sozialen im Gesellschaftlichen Diskurs, [w:] tegoż, Kulturen - Identitäten - Diskurse. Perspektiven Europäischer Ethnologie, Berlin 1995, s. 11-30.

${ }^{35}$ Zagadnieniami ezoteryzmu zajmują się m.in. paryska katedra Histoire de l'ésotérisme occidental na Sorbonie (obecnie część École pratique des hautes études), londyński Instytut Warburga, Center for History of Hermetic Philosophy and Related Currents na Uniwersytecie w Amsterdamie oraz Exeter Centre for the Study of Esotericism (EXESESO). 
Powyższe określenia nie oddają jednakże w pełni sposobu funkcjonowania (,życia”) kultury. Tendencji do hegemonii, petryfikacji, systematyzacji, ujednolicenia, kodyfikacji oraz hierarchizowania wartości i wzorów (kultura stanowi bowiem potężny oręż władzy, presji na świadomość, narzędzie kontroli dyskursów i sprawowania „rządu dusz”) przeciwstawia się wielogłosowość, różnorodność, dialogowa polaryzacja. Starcie tego rodzaju zaprezentował sugestywnie Michaił Bachtin w pracy Творчество Франсуа Рабле и народная культура средневековья и Ренессанса (Moskwa 1965, 1990). Ukazuje ona historyczny spór karnawałowej kultury śmiechu i groteski z kultywującą serio, powagę i abstrakcyjną idealizację kulturą oficjalną. Współczesnym obrazem konfliktowych relacji polarnie usytuowanych kultur (cywilizacji) stała się z kolei publicystyczna - krytykowana zresztą za nadmierne uproszczenia - książka Samuela Huntingtona The Clash of Civilizations and the Remaking of World Order (1996). Wieszcząc koniec wieku ideologii, amerykański politolog uznał, iż osią sporu na przełomie XX i XXI wieku stały się trudne do pogodzenia różnice kulturowe i religijne. W tym też względzie kultura tworzy swego rodzaju złożone, wielowarstwowe, ruchome, reprezentowane przez różne kręgi (,podsystemy”) kulturowe coincidentia oppositorum. W rozsupłaniu i konkretyzacji tej formuły mieści się jedno z kluczowych zadań kulturologii.

Rzeczą istotną z punktu widzenia kulturologii jest więc to, że kultura powstaje w toku antropogenezy. Kształtowana przez człowieka, zwrotnie oddziałuje zarówno na niego samego, jak też na jego działalność oraz na otaczający go świat cywilizacji i przyrody. Podlega, z jednej strony, uwewnętrznieniu, formuje osobowość, psychikę i zachowania jednostek. $Z$ drugiej zaś strony, wpływa na relacje międzyludzkie oraz reguluje życie zbiorowe. Jej formy, raz powołane do życia i puszczone w obieg, uzyskują walor społeczny. Reprezentują swego rodzaju dobro wspólne. Podlegają zobiektywizowaniu, usamodzielnieniu, urzeczowieniu i znaturalizowaniu. Tracą też nierzadko osobową więź z twórcami, wynalazcami czy prawodawcami. 
Stają się anonimowe i bezosobowe. Zamieniają się niejednokrotnie w obowiązujące periodycznie „tabu” i „nieprzekraczalne normy”. W rzeczywistości trudno byłoby jednakże wśród tych ostatnich wyszczególnić takie, które w dłuższej perspektywie skutecznie oraz trwale oparły się przemianom i relatywizującemu działaniu czasu.

\section{BIBLIOGRAFIA:}

Joaquín Jareño Alarcón, Anthropology, Indeterminacy and Incommensurability,

http://hottopos.com/convenit6/jareno.htm [data dostępu: 10.10.2015].

Moritz Baßler, New Historicism, Cultural Materialism und Cultural Studies, [w:] Konzepte der Kulturwissenschaften. Theoretische Grundlagen - Ansätze - Perspektiven, red. Ansgar Nünning, Vera Nünning, Stuttgart 2003.

Moritz Baßler, Towards a Poetics of Culture, „Southern Review”, vol. 20, no.1, Mar 1987, s. 3-15.

Doris Bachmann-Medick, Kulturanthropologie, [w:] Konzepte der Kulturwissenschaften. Theoretische Grundlagen - Ansätze - Perspektiven, red. Ansgar Nünning, Vera Nünning, Stuttgart 2003.

Hartmut Böhme, Klaus Scherpe, Zur Einführung, [w:] Literatur und Kulturwissenschaft, red. H. Böhme, K. Scherpe, Hamburg 1996. 
Robert L. Carneiro, Leslie A. White, [w:] Totems and Teachers: Key Figures in the History of Anthropology, red. Sydel Silverman, Walnut Creek 2004.

Georges Charbonnier, Entretiens avec Claude Lévi-Strauss, Paryż 1969.

Culture and the Unconscious, red. Caroline Bainbridge, Susannah Radstone, Michael Rustin, Candida Yates, Palgrave Macmillan 2007.

Г.В. Дьяконов, Диалогийная концепция эстетики и литературоведения М.М. Бахтина, „Социіальна психологиія” 2006, № 6 (20), s. 35-46.

William T. Fagan, Literacy and Cultural Thoughtfulness: the Power and Helplessness within and beyond Cultural Boundaries, http://www. literacy.org/sites/literacy.org/files/publications/fagan_cult_lit_prac_in_ Canada_96.pdf [data dostępu: 25.10.2015].

Said Faiq, The Discourse of Intercultural Translation, „Intercultural Communication Studies" 2004, XIII, s. 3.

James Gee, What is Literacy?, [w:] Rewriting Literacy: Culture and the Discourse of the Other, red. Candace Mitchell, Kathleen Weiler, New York 1991.

Christian Gerlach, Wu-Wei in Europe. A study of Eurasian economic thought, Londyn 2005.

Wolfgang Kaschuba, Anmerkungen zum Gesellschaftsvergleich aus ethnologischer Perspektive,

http://edoc.hu-berlin.de/oa/bookchapters/resf43HGISZo/ PDF/23uDV5SvKdUoc.pdf [data dostępu: 13.10.15].

Wolfgang Kaschuba, Kulturalismus. Vom Verschwinden des Sozialen im Gesellschaftlichen Diskurs, [w:] tegoż, Kulturen - Identitäten - Diskurse. Perspektiven Europäischer Ethnologie, Berlin 1995.

Alfred L. Kroeber, Clyde Kluckhohn, Culture. A Critical Review of Concepts and Definitions, Cambridge 1952.

Adam Kuper, Culture. The Anthropogist's Account, Cambridge 1999. 
Jurij Lotman, Культура и взрыв, [w:] tegoż, Семиосфера, С.-Петербург 2000.

Jurij Lotman, О семиотическом механизме культуры (1971), [w:] tegoż, СЕМИОСФЕРА. Культура и взрыв. Внутри мысляяиих миров. Статьи. Исследования. Заметки (1968-1992), Sankt Petersburg 2000.

John A. Mears, Integrating Prehistory into the Study Humanity's Common Past, [w:] Teaching World History: A Resource Book, red. Heidi Roupp, Londyn 2015.

Michael Minkov with contribution by Geert Hofstede, Cross-Cultural Analysis. The Science and Art of Comparing the World's Modern Societies and Their Cultures, Sage 2013.

Claus-Michael Ort, Kulturbegriffe und Kulturtheorie, [w:] Ansgar Nünning, Vera Nünning (Hgs), Konzepte der Kulturwissenschaften. Theoretische Grundlagen - Ansätze - Perspektiven, Stuttgart 2003.

Cyprian K. Norwid, Pisma wszystkie, t. 2, Warszawa 1971.

Татьяна М. Обухова, «Вненаходимость» в диалоге культур (по работам М.М Бахтина), [w:] Языки. Культуры. Перевод. Материалы международного научно-практического форума, Москва 2013.

Hilary Putnam, Reason, Truth and History, Cambridge 1981.

William H. Sewell, The Concepts of Culture, [w:] Beyond the Cultural Turn New Directions in the Study of Society and Culture, red. Victoria E. Bonnell, Lynn Hunt, Berkeley 1999.

Edward G. Singerland, Effortless Action: Wu-wei as Conceptual Metaphor and Spiritual Ideal in Early China, Oxford 2003.

The Question of Animal Culture, red. Kevin N. Laland i Bennett G. Galef, Cambridge, Mass 2009.

Leslie L. White, The Concept of Culture, „American Anthropologist”, New Series, Vol. 61, No. 2 (Apr., 1959), s. 227-251. 


\section{What is Culturology?}

Culturology as a distinct reflection of culture that emerged in the second half of the twentieth century, and the so-called cultural turn in the humanities (the turn that realised their cultural background and base) became the impetus for its development. The article tries to clarify what is the term in question, the subject of its research, what kind of theoretical assumptions does it make in relation to this subject and what specific learning goals does it face. One of the key question of culturology concerns culture: what are its limits, how its forms may vary in space and time, and whether or to what extent they form - despite differences - a community, unity and totality. The article indicates the dynamic, processual and creative nature of culture on one hand, and its openness on the other, consequently proving the utopian character of aspirations willing to establish once and for all an unchangeable 'essence' of culture as well as its timeless determinants and systemic framework. The article consists of three parts: 1) Context, subject and properties of culturology, 2) Delimitations of culture, 3) Acceleration, literacy, multiculturalism, culturalism.

Keywords: culturology, delimitations of culture, multiculturalism, culturalism. 


\section{Nowości Wydawnictwa UKSW}

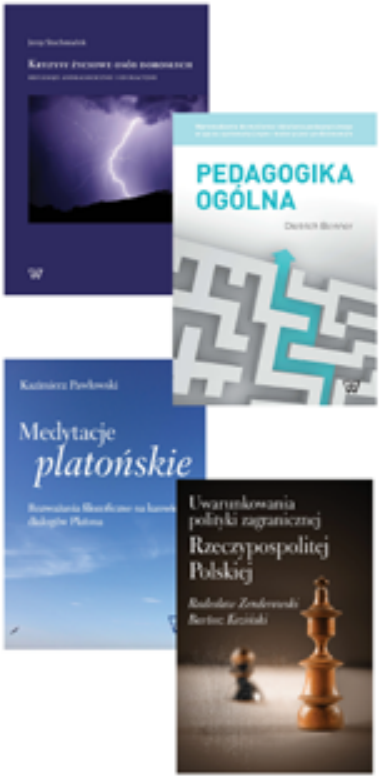

- Jerzy Stochmiałek, Kryzysy życiowe osób dorosłych

- Dietrich Benner, Pedagogika ogólna

- Kazimierz Pawłowski, Medytacje platońskie. Rozważania filozoficzne na kanwie dialogów Platona

- Bartosz Koziński, Radosław Zenderowski, Uwarunkowania polityki zagranicznej Rzeczypospolitej Polskiej

Więcej informacji na stronie: www.wydawnictwo.uksw.edu.pl 